\title{
The Effect of Natural Zeolite Clinoptilolite on Aquarium Water Conditions
}

\section{Akvaryum Su Koşulları Üzerine Doğal Zeolit Klinoptilolitin Etkisi}

\author{
Research Article
}

Meryem Öz ${ }^{1 *}$, Dilek Şahin², Orhan Aral'

'Sinop University, Fisheries Faculty, Department of Aquaculture, Sinop, Turkey.

${ }^{2}$ Sinop University, Vocational School, Underwater Technology Programme, Sinop, Turkey.

\section{A B S TR ACT}

$\mathrm{D}$ etermination of the effects natural zeolite clinoptilolite on the aquarium water conditions was assessed in this study. For this purpose 2 different applications were performed. For the first application 7 grams of zeolite (Z7) was put to aquarium directly and for the second application same quantity of zeolite was put inside a net bag (NZ7) and placed in the aquarium. The third group was described as the control group without zeolite (C). Equal amounts of fish feed were added into the aquariums of the three groups and data on water quality parameters (temperature, $\mathrm{pH}, \mathrm{NH}_{3}, \mathrm{TAN}$ ) were collected for 12 days. At the end of the trial, level of ammonia which increased in proportion to time was lower in groups with zeolite after day 4, compared to the control group. While no statistical difference was found among mean water temperatures of trial groups $(P>0.05)$, it was found that the difference between $\mathrm{pH}$ and ammonia levels was significant $(P<0.05)$.

\section{Key Words}

Aquarium, Water conditions, Zeolite, Clinoptilolite.

\section{ÖZET}

\begin{abstract}
A raştırmada, doğal zeolit klinoptilolitin akvaryum su koşulları üzerine yaptığı etkilerin belirlenmesi A planlanmıştır. Bu amaç ile 2 farklı uygulama yapılarak deneme grupları oluşturulmuştur. ilı uygulama için tül torba olmaksızın 7 gram zeolit (Z7), ikinci uygulama için ise tül torba içerisinde 7 gram zeolit (TZ7) akvaryumlara yerleştirilmiştir. Üçüncü grup ise zeolit konulmayarak kontrol grubu olarak düzenlenmiştir (K). Her üç grubun akvaryumlarına eşit miktarda balık yemi eklenmiş ve 12 gün süresince su koşulları (sıcaklık, pH, $\mathrm{NH}_{3}$, TAN) ile ilgili veriler toplanmıştır. Deneme sonunda, süreyle orantılı olarak artan amonyak miktarının; zeolitli gruplarda kontrol grubuna kıyasla 4. günden sonra daha düşük miktarlarda olduğu belirlenmiştir. Deneme gruplarında belirlenen ortalama su sıcaklık değerleri arasında istatistiki bir fark belirlenmezken (P>0.05), pH ve amonyak değerleri arasındaki farkın istatistiki olarak önemli olduğu belirlenmiştir $(P<0.05)$.
\end{abstract}

\section{Anahtar Kelimeler}

Akvaryum, Su koşulları, Zeolit, Klinoptilolit.

Article History: Received: Jun 22, 2015; Revised: Dec 24, 2015; Accepted: Mar 20, 2016; Available Online: Apr 1, 2016. DOI: $10.15671 /$ HJBC.20164418130

Correspondence to: M. Öz, Sinop University, Fisheries Faculty, Department of Aquaculture, Sinop, Turkey. 


\section{INTRODUCTION}

- nsuring ideal water quality parameters is one - of the most important functions in setting the suitable water condition for aquarium organisms. Water quality parameters tend to deviate from suitable range due to metabolic waste of live animals and waste materials which are not consumed during feeding. In order to control aquarium water conditions, proper filtration techniques and materials must be used. Among filtration materials, natural zeolite clinoptilolite has drawn attention due to being a natural economic and most importantly an effective ammonia adsorption material. Many studies are carried out so far concerning the use of clinoptilolite on water purification [1-10].

Particularly, ammonia concentrations in waste water of domestic and industrial origin are much higher than concentrations in aquaculture systems. Because of this difference in concentrations, data obtained from waste water studies is not very likely to be beneficial for aquaculture. In this regard, it is important both for aquaculture sector and for the utilization of zeolite, to research its use in aquaculture systems. The use of clinoptilolite for water purification is related to its several physical and chemical characteristics. These are fractal dimension, conditioning, cation content of clinoptilolite, water $\mathrm{pH}$, water temperature, etc. [10]. In this study, it was planned to determine the effects of using zeolite inside bag and bagless on aquarium water conditions.

\section{MATERIALS and METHODS}

Experiments were conducted in plastic aquariums with 5 liter of water. The experiment was designed in triplicate for each group without any fish. The basic physico-chemical parameters of the water were measured with a YSI hand-held meter (Yellow Springs Instruments). In this study, Western Anatolia clinoptilolite, which is the most important zeolite source of Turkey in terms of the size of its reserves and its utilization potential, was used as a filter material. 1-3 mm filter material (FILTERCLINO $^{\mathrm{TM}}$ ), which was broken down to smaller pieces, was obtained from the producer firm. Ammonium $\left(\mathrm{NH}_{4}^{+}\right)$exchange capacity of zeolite used in the study was between 1.6-2.1 meq/g $(1.8$ $\mathrm{meq} / \mathrm{g}$ in average) for the natural product [11]. Feed used in the trial contained $39.90 \%$ crude protein, $6.66 \%$ crude fat and $6.45 \%$ crude ash.

Trial was carried out in 3 groups. 7 grams of zeolite were placed inside the aquarium without a net bag for the first group (Z7), while for the second group (NZ7) 7 grams of zeolite were placed inside the aquarium inside a net bag. Zeolite was not used in third group (control, C). 5 liters of water and 2.5 grams of fish feed were added into the aquariums only one time during study and aeration was provided regularly using air pump with air stone. Data on water temperature, $\mathrm{pH}$ and ammonium levels were collected.

During the study ammonia $\left(\mathrm{NH}_{3}\right.$ and TAN) levels were calculated from $\mathrm{NH}_{4}{ }^{+}$, water temperature and $\mathrm{pH}$ values [12-14].

Statistical analysis of the study results was performed with "Minitab Release 15 for Windows" software. Parametric tests (ANOVA) were performed on data which met the preconditions of variance analysis, while non-parametric tests (Kruskal-Wallis) were performed on data which did not meet the preconditions of variance analysis [15].

\section{RESULTS and DISCUSSION}

In this study, it was found that clinoptilolite was particularly effective in reducing ammonia and TAN levels. Water quality parameters analyzed on a daily basis are given in Table 1 .

It was found that the total ammonia nitrogen (TAN) concentration of group Z7 and NZ7 were significantly lower than the control group ( $P$ < 0.05).

Ammonia concentrations were calculated using $\mathrm{NH} 4$, water temperature and $\mathrm{pH}$ levels measured throughout the study and daily $\mathrm{NH}_{3}$ levels of trial groups are given in Figure 1.

When ammonia concentration reached upon $0.3 \mathrm{mg} / \mathrm{l}$ (day 3 and later), a positive difference was observed between groups. Ammonia concentration reached the highest level in the 
Table 1. Mean water quality parameter values during experiment (mean $\pm \mathrm{SE}$ ).

\begin{tabular}{ccccc}
\hline Trial Groups* & & \multicolumn{2}{c}{ Water Quality Parameters } & \\
& $\begin{array}{c}\text { Water Temperature } \\
\left({ }^{\circ} \mathrm{C}\right)\end{array}$ & $\mathrm{pH}$ & $\begin{array}{c}\text { Ammonia }\left(\mathrm{NH}_{3}\right) \\
(\mathrm{mg} / \mathrm{l})\end{array}$ & $\begin{array}{c}\text { Total Ammonia } \\
\text { Nitrogen (TAN) } \\
(\mathrm{mg} / \mathrm{l})\end{array}$ \\
\hline $\begin{array}{c}23.83 \pm 0.20^{\mathrm{a}} \\
\text { Zeolite (Z7) }\end{array}$ & $8.60 \pm 0.02^{\mathrm{a}}$ & $0.55 \pm 0.09^{\mathrm{ab}}$ & $3.049 \pm 0.45^{\mathrm{b}}$ \\
\hline $\begin{array}{c}\text { Netbag Zeolite } \\
(\mathrm{NZ7})\end{array}$ & $23.83 \pm 0.19^{\mathrm{a}}$ & $8.53 \pm 0.02^{\mathrm{b}}$ & $0.23 \pm 0.03^{\mathrm{b}}$ & $1.549 \pm 0.20^{\mathrm{b}}$ \\
\hline Control (C) & $23.97 \pm 0.20^{\mathrm{a}}$ & $8.47 \pm 0.03^{\mathrm{b}}$ & $0.82 \pm 0.16^{\mathrm{a}}$ & $5.860 \pm 1.17^{\mathrm{a}}$ \\
\hline
\end{tabular}

*a,bDifferent superscripts within column represent significant differences $(P<0.05)$.

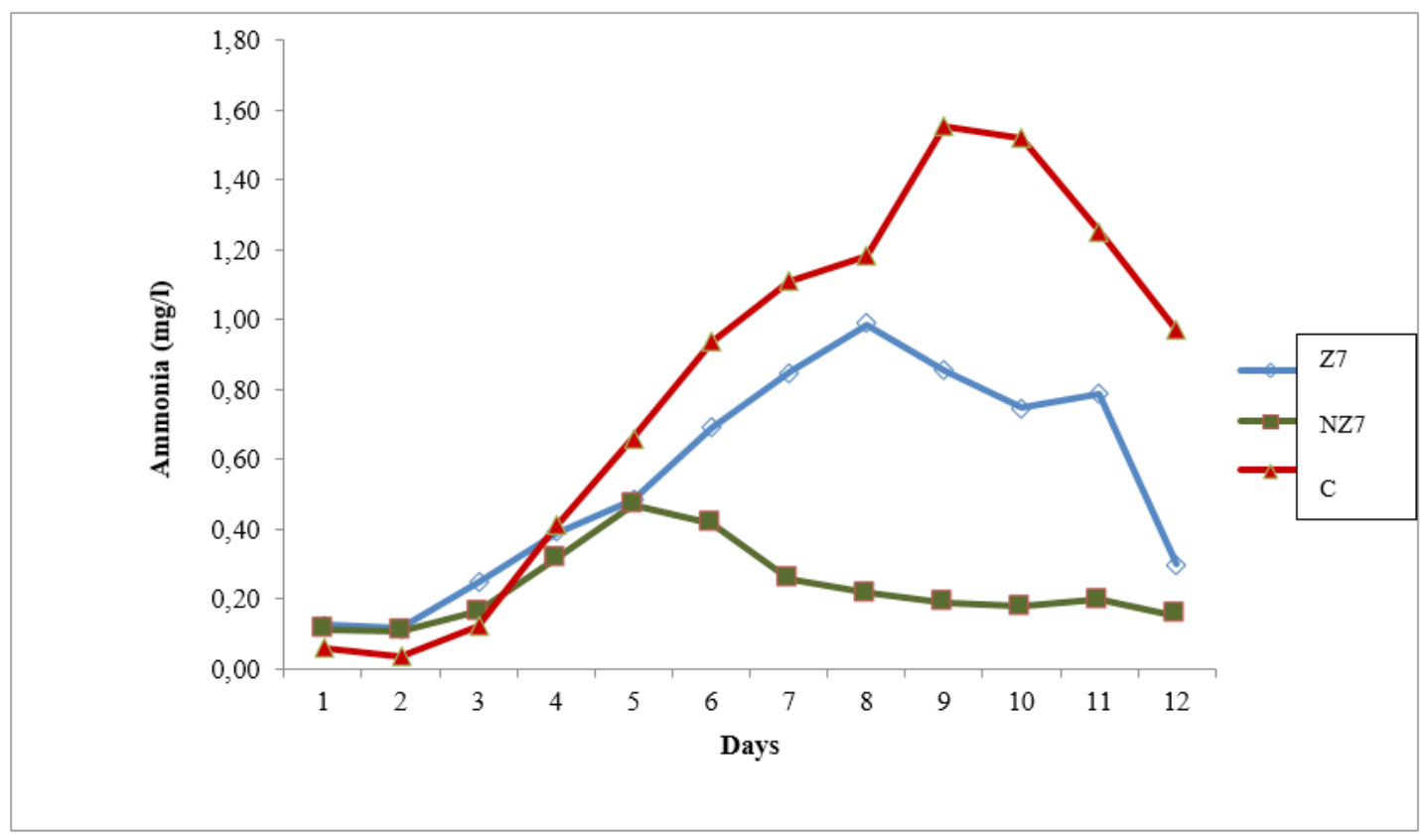

Figure 1. Daily ammonia levels of trial groups.

control group on day $9^{\text {th }}$ of the study $(1.6 \mathrm{mg} / \mathrm{l})$, and on the same day it was $0.9 \mathrm{mg} / \mathrm{l}$ and $0.2 \mathrm{mg} / \mathrm{l}$ respectively in groups comprising natural zeolite clinoptilolite.

TAN levels of the aquariums with clinoptilolite were found to be lower compared to the control group ( $P<0.05$ ). So it was found that the effect of natural zeolite clinoptilolite had a positive effect on aquarium water conditions in terms of reducing the increasing TAN concentration levels. Aquarium fish are in a limited capacity of water. So keeping water conditions within the ideal range is one of the most important activities to be performed. The most important factors affecting water conditions are metabolic waste of live animals and unconsumed feed [16]. It was stated that each $100 \mathrm{~g}$ feed protein consumed by the fish was converted into $5.6 \mathrm{~g}$ ammonia by the fish [16]. It was reported that toxicity of unionized ammonia $\left(\mathrm{NH}_{3}\right)$ began at $0.05 \mathrm{mg} / \mathrm{l}$, while it caused death at $2 \mathrm{mg} / \mathrm{l}$ for many fish species [17]. In general, $0.02 \mathrm{ppm}$ is considered as limit for ammonia in aquaculture [18].

In this study, the use of natural zeolite clinoptilolite as a filter material was investigated. At the end of the 12-day study; it was found that 7 grams of zeolite inside a net bag reduced increasing ammonia concentrations at a statistically significant level compared to the control group. It is considered that the use of zeolite inside a net bag will have a positive effect to prevent coarse particles inside aquarium water from obstructing 
the pores of zeolite and decreasing ammonium retention. Use of zeolite inside a net bag is also suitable to prevent turbidity. In a study which analyzed the effects of bentonite in the diets of aquarium fish and in aquarium water, [19] emphasized that bentonite could cause turbidity in aquarium water. Furthermore, when the zeolite is saturated, it can be reused after treatment with salt water. In this process called conditioning, zeolite should be removed from fish production area. It is considered that using zeolite inside a net bag will be practical in this regard.

At the end of the study, it was found that the use of 7 grams of zeolite inside/outside a net bag, reduced ammonia and TAN concentration in aquarium water. However, ammonia concentration must be at low levels for fish production. Difference between groups with zeolite is statistically insignificant as regards ammonia adsorption levels. However, use of zeolite in the aquaculture a net bag inside will have advantages such as higher ammonia adsorption levels, prevention of aquarium water turbidity, and easy removal from production area for conditioning process. Therefore, use of zeolite inside a net bag can be recommended.

\section{ACKNOWLEDGEMENTS}

We thank Enli Mining Corporation for suppyling zeolite.

\section{References}

1. N.A. Booker, E.L. Cooney, A.J. Priestley, Ammonia removal from sewage using natural australian zeolite, Water Sciences Technology, 34 (1996) 17-24.

2. Y. Sabah, E. Sabah, A. Berktay, Doğal zeolitlerin (klinoptilolit) su yumuşatımında kullanımı Pamukkalae Üniv. Müh. Fak. Mühendislik Bilimleri Dergisi, 5 (1999) 1155-1161.

3. H. Emadi, J.E. Nezhad, H. Pourbagher, In vitro comparison of zeolite (clinoptilolite) and activated carbon as ammonia absorbants in fish culture, Naga, The Iclarm Quarterly, 24 (2001) 18-20.

4. T.C. Jorgersen, L.R. Weatherley, Ammonia removal from wastewater by ion exchange in the presence of organic contaminants, Water Research, 37 (2003) 1723-1728.
5. A.R. Rahmani, A.H. Mahvi, A.R. Mesdaghinia, S. Nasseri, Investigation of ammonia removal from polluted waters by clinoptilolite zeolite. International Journal of Environmental Sciences \& Technology, 1 (2004) 125-133.

6. A. Mazeikiene, M. Valentukevicien, M. Rimeik, A.B. Matuzevicius, R. Dauknys, Removal of nitrates and ammonium ions from water using natural sorbent:zeolites (clinoptilolite), Journal of Envirenmental Engineering and Landsapace Managament, 16 (2008) 38-44.

7. M. Zabochnicha-Swiate, K. Malinska, Removal of ammonia by clinoptilolite. Global Nest Journal, 12 (2010) 256-261.

8. D. Danabaş, T. Altun, Effects of zeolite (clinoptilolite) on some water and growth parameters of rainbow trout (Oncorhynchus mykiss Walbaum, 1792), Digest Journal of Nanomaterials and Biostructures, 6 (2011) 1111-1116.

9. K. Margeta, N.Z. Logar, M. Siljeg, A. Farkas, Natural zeolites in water treatment- how effective is their use. http://dx.doi.or./10.5772/50738.Chapters, Intech open sciences/open minds (2013).

10. Q. Deng, Ammonia removal and recovery from using natural zeolite: An integrated system for regeneration by air stripping followed ion exchange, A Thesis, University of Waterloo, Civil Engineering Waterloo, Ontorio, Canada, (2014) 121.

11. Anonim, www.enlimining.com.tr (Available date: 07/03/2007)

12. EPA, Ambient water quality criteria for ammonia. United States Environmental Protection Agency, (1999) 99-104.

13. K. Emerson, R.C. Russo, R.E. Lunt, R.V. Thurston, Aqueous ammonia equilibrium calculations: effect of $\mathrm{pH}$ and temperature, Journal of the Fisheries Research Board of Canada, 32 (1975) 2379-2383.

14. YSI, YSI Professional plus user manual, (2007) 79.

15. J.H. Zar, Biostatistical Analysis, Books a la Carte Edition (5th Edition) (2010) 960.

16. C. E. Boyd, Water quality in ponds for aquaculture, Auburn, AL: Auburn University, Alabama Agricultural Experiment Station, Pres. 482 (1990) (It was taken: Boyd, C. E., Practical aspects of chemistry in pond aquaculture, The Progressive Fish Culturist, 59 (1997) 85-93).

17. R.F. Floyd, C. Watson, P. Denise, B.P. Deborah, Ammonia in aquatic systems. IFAS FA-16, http://edis. ifas.ufl.edu/fa 004_(Available date: 20/01/2015).

18. L. Swann, A basic overview of aquaculture, Funding has been Provided Through United States Department of Agriculture Grant, 88 (1992) 10.

19. D.J. Booth, Effects of dietary and free bentonite on ammonia bulidup in aquarium fish, Australasian Journal of Ecotoxicology, 5 (1999) 149-152. 